\title{
Barriers in Tuberculosis Treatment in Rural Areas (Tengger, Osing and Pandalungan) in Indonesia Based on Public Health Center Professional Workers Perspectives: a Qualitative Research
}

\author{
R Endro Sulistyono1, Tantut Susanto2, and Rr Dian Tristiana3 \\ 1 Diploma of Nursing, Faculty of Nursing, Universitas Jember, Indonesia \\ 2 Faculty of Nursing, Universitas Jember, Indonesia \\ 3 Faculty of Nursing, Universitas Airlangga, Indonesia
}

\begin{abstract}
Introduction: Tuberculosis (TB) is still one of the main health problems in Indonesia. Various efforts have been made by the government to handle the TB problem in Indonesia, one of which is implementing a direct observed therapy short course (DOTS) program. However, the handling of TB disease in Indonesia, especially in rural areas is still not optimal. This study aims to explore barriers to the handling of TB in rural areas from the perspective of public health center professionals.
\end{abstract}

Methods: This study is a qualitative research with a phenomenological approach. Sampling was done by purposive sampling with a sample of 8 participants. Data is collected through focus group discussions. Thematic analysis is carried out using colaizi step.

Results: This study obtained two themes. Theme 1 is the barriers in the aspect of TB patients and Theme 2, which is barriers from the aspect of health care facilities.

Conclusion: This study obtained two themes. Theme 1 is the barriers in the aspect of TB patients and Theme 2, which is barriers from the aspect of health care facilities.

\section{ARTICLE HISTORY}

Received: October 302018

Accepted: October 282019

\section{KEYWORDS}

tuberculosis; rural; health provider; qualitative research

\section{CONTACT}

\section{R Endro Sulistyono} $\checkmark$ radendro1988@unej.ac.id $\equiv$ Diploma of Nursing, Faculty of Nursing, Universitas Jember, Indonesia

Cite this as: Sulistyono, R.E., Susanto, T., Tristiana, R. D. (2019). Barriers in Tuberculosis Treatment in Rural Areas (Tengger, Osing and Pandalungan) in Indonesia Based on Public Health Center Professional Workers Perspectives: a Qualitative Research. Jurnal Ners, 14(1), 62-68. doi:http://dx.doi.org/10.20473/jn.v14i1.10270

\section{INTRODUCTION}

Tuberculosis is an inflammatory disease of the lung parenchyma caused by the bacterium Mycobacterium tuberculosis. WHO states that one third of the world's population has been infected with tuberculosis bacteria. Every second there is one person infected with tuberculosis. Although Indonesia has achieved remarkable progress over the past decade, tuberculosis (TB) is still one of the top four causes of death in Indonesia (Usaid, 2017). Based on Global Tuberculosis Report data in 2016, Indonesia ranks second behind India with the most TB patients. The new TB cases in Indonesia in 2016 were 360,565 cases (WHO, 2017).

TB treatment in Indonesia is a Direct Observed Therapy Short-Course (DOTS) strategy promoted by the World Health Organization with the main goal of achieving successful treatment of TB treatment and a low Case Notification Rate. The aim of this new case discovery program is to find new cases as early as possible so that they can be handled more quickly and do not cause severe complications (WHO, 2013). TB treatment in rural areas is still not optimal. Some obstacles related to the handling of TB are obstacles to the handling of $\mathrm{TB}$ diseases such as access to difficult health care places and failure to diagnose TB disease, financial problems (Sagbakken, Frich, \& Bjune, 2008), public attitudes and beliefs about TB disease, low level of knowledge about TB (Sullivan, Esmaili, \& Cunningham, 2017), stigma and lack of social support (Ahmed \& Martin, 2018).

Transmission of TB bacteria by individuals who have not been diagnosed with TB or who have not received treatment yet is still a major problem related to Tuberculosis. Previous study related to 
prevention efforts by TB sufferers and families have been conducted (Hutama, Riyanti, \& Kusumawati, 2019; Pratiwi, Betty, Hargono, \& Widya, 2012), however the literature related to barriers perceived by public health professional workers in the treatment of TB, especially in rural areas, still needs to be explored. Moreover, the health service system in Indonesia has experienced many changes related to TB treatment management policies. Indonesia is a developing country with many rural areas with low levels of health literacy and unproportional public health facilities spread. Health promotion carried out by health workers has often encountered obstacles such as differences in community characteristics, coverage of areas far from the place of service, as well as the dissemination of several topics at once (Tuharea, Suparwati, \& Sriatmi, 2014).

Professional nursing practices often experience problems due to cultural differences between modern culture and traditional culture. Barriers related to the handling of TB in rural areas need to be explored to find out what problems can be handled at the public health center and find appropriate ways to reduce the incidence of TB in Indonesia. The barriers that felt by public health professional workers is a personal experience that cannot be measured quantitatively. So this study uses a qualitative approach to underpin the study questions. This study aims to explore the barriers perceived by publich health professionals while dealing with TB treatments in rural areas.

\section{MATERIALS AND METHODS}

\section{Research Design}

This study aims to explore barriers to the handling of TB disease in rural communities from the perspective of public health professional workers who carry out TB treatment programs at public health centers. This study uses qualitative research methods with a phenomenological approach.

\section{Setting}

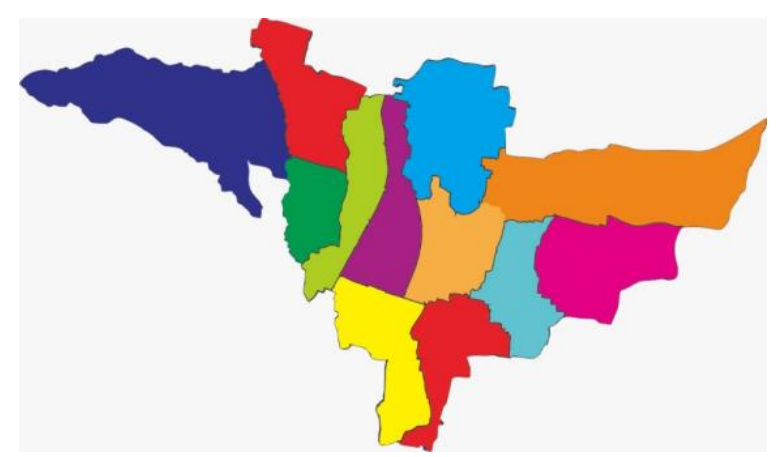

Figure 1 Map of Klakah District

The research area, which is conducted in a public health center, this public health center is handling 12 villages in the klakah sub-district. The population was 54,156 people which is spread in 12 villages and consists of 60 sub villages. Health services facility in Klakah are one public health center with one supporting public health center, and one medical clinic. The number of TB patients in the Klakah public health center has increased from 53 people in 2017 to 83 people in 2018. Many TB patients in the klakah public health center have not been recorded.

The active TB case finding program is a new program that is implemented in the Klakah public health center and is still not optimal. Sputum examination is still the only diagnostic examination performed at the klakah clinic. X-ray examination is done in a regional hospital that is quite far from the Klakah public health center.

\section{Participants}

Participants in this study were public health professional workers who handling of TB programs in Tengger, Osing and Pandalungan areas. The number of participants in this study is 8 health professional workers who have different educational backgrounds and professions.

\section{Data Collection}

The study was conducted at the public health center which handlings 12 villages in the Pandalungan, Tengger and Osing areas which were carried out from July to September 2018. Qualitative data collection was carried out by Focus Group Discussions (FGD) method for public health professional workers who served as Tuberculosis control program implementers.

An interview guide was developed to collect information during the FGD process using voice recorders and field notes taken during the discussion process to record findings in gathering information and confirm the validity of the researcher interpretation. FGDs were conducted using Indonesian language and Madura language (the local language of the area where the study was conducted). The interview question was developed with an opening question in the form of "how are the barriers that perceived by public health professional workers regarding the care of TB patients in rural areas?". This FGD group is considered a natural group because most participants know each other so that it is beneficial for the discussion groups dynamics. The discussion activity was carried out in one of the health centers which was moderated by one of the researchers. The discussion process was recorded using a recording device which was then transcribed and one of the other researchers recorded during the discussion process related to the discussion group dynamics.

\section{Data Analysis}

Qualitative data analysis in this study used analysis using Colaizi steps (Streubert \& Carpenter, 2003). Firstly, the analysis were started with writing the interview in written form (verbatim). Secondly, the verbatim transcript of all of the participants was read repeatedly to identify sentences or words with a particular meaning and provide them with a code 
based on the similarities and differences. Afterwards, the process also involved explaining the meaning of the significant sentences and collecting and organizing the formulation of category descriptions into a collection of themes, which resulted in the validation theme. Categories and themes were extracted from the main idea of the statement and the sentence stated by the participants during the interview process (Tristiana, Yusuf, Fitryasari, Wahyuni, \& Nihayati, 2018).

\section{Trustworthines}

The data analysis process is carried out simultaneously with the data retrieval process. Data retrieval is stopped when reaching data saturation, where no new themes or new categories are found. The researcher checks all participants after verbatim has been completed. To minimize subjectivity, every verbatim result is analyzed by two researchers. The researcher reads the transcript repeatedly to identify important and significant words or sentences that have meaning and encode them based on similarities and differences. Every transcript was then coded systematically against the code frame. Codes were merged into categories and then these categories were organized into themes. Disagreements were discussed among the research team to reach a final consensus. The principal researcher revisited the main points of the findings with the participants and asked whether they were consistent with their experiences. Data analysis was conducted in Bahasa language and the final report was translated into English.

\section{Ethical Consideration}

The health ethics committee of the Faculty of Dentistry at Jember University approved the implementation of this research.

\section{RESULTS}

This study involved 8 public health centers professional workers who handling with TB disease at Klakah Public Health Center (Table 1): five women and three men aged between 34-48 years with the participant profession namely one doctor, six nurses and one medical analyst.

The emerging theme was formulated on the basis of the participants' answers to the interview in the Focus Group Discussion questions and the notes during the discussion process. This study has two themes that were explained in order to reflect the purpose of the study.

\section{Barriers from the patient's aspects \\ Discomfort in the side effects of $T B$ drugs}

Public health professional workers said that barriers in efforts to treat TB patients, namely discomfort feeling with anti TB drug side effects, health professional workers said some TB patients stopped
Table 1 Demographic Data of Public Health Professional Participants

\begin{tabular}{lcc}
\hline Characteristic & $\mathrm{N}=8$ & $\begin{array}{c}\text { Mean Age (in } \\
\text { Years) }\end{array}$ \\
\hline Age & & 38.5 \\
Sex & 5 & \\
$\quad$ Female & Male & \\
Ethnicity & 3 & \\
Professional background & & \\
$\quad$ & & \\
$\quad$ Nurse & & \\
$\quad$ Medical doctor & 1 & \\
$\quad$ Analyst & 1 & \\
\hline
\end{tabular}

Table 2 Theme and Category

\begin{tabular}{|c|c|}
\hline Theme & Category \\
\hline $\begin{array}{l}\text { Barriers From } \\
\text { Patients } \\
\text { Aspects }\end{array}$ & $\begin{array}{l}\text { Discomfort Feeling for Anti TB } \\
\text { drugs Side Effects } \\
\text { Lack of knowledge of TB } \\
\text { Lack of Awareness of TB } \\
\text { Non-adherence of TB Treatment } \\
\text { Culture and Beliefs }\end{array}$ \\
\hline $\begin{array}{l}\text { Barriers From } \\
\text { health Facility } \\
\text { Aspects }\end{array}$ & $\begin{array}{l}\text { Health Facility Access } \\
\text { Human Resources } \\
\text { Lack of cross-sector } \\
\text { colloborations }\end{array}$ \\
\hline
\end{tabular}

taking TB drugs due to discomfort with the perceived side effects of anti TB drugs:

"TB patients said that taking anti tuberculosis medicine turns out to be unpleasant feeling, nausea, dizziness, muscle aches, people sometimes unable to endure the side effects that sometimes torture, so they decide to stop the treatment" -Nurse-

\section{Lack of knowledge about Tuberculosis}

Public health professional workers said that TB patients consider symptoms of cough to be just a common disease:

"When people are reminded of the symptoms of coughing, they answer that only a normal cough and they are normal and are not considered a serious illness" -Medical doctor-

\section{Lack of self-awareness}

Most public health professional workers said that the lack of self-awareness of TB patients about their illness, which is not willing to take their own medication and be evaluated, as stated:

"Awareness level of TB patients is lacking, those who take anti TB drugs in the public health center are other people, even though they are actually capable, so treatment evaluation cannot be done" -Nurse- 
Lack of awareness of TB patients related to unclean environment and habit of spitting carelessly despite knowing that TB is an infectious disease:

"In rural area, environment pollution chicken cage, mix with home, ODR spit randomly" - Medical doctor -

Awareness regarding the use of masks to prevent transmission is not carried out by TB sufferers:

"The sick only wear a mask if they go to the health center, but not to other places" awareness to prevent transmission to other people is still low even though often delivered when coming to the health center "-Nurse-

\section{Non-adherence to treatment}

The disobedience of TB patients in the TB treatment process is delivered by health workers, TB patients do not take drugs on time, namely:

"Take it not on schedule, up to a week and two weeks and underestimate taking medicine" -Nurse-

Non-adherence to TB treatment is caused because the patient feels bored, every day must take medication:

"The patient feels the drug is bored with anti TB drugs, the level of adherence is only $80 \%$, the rate of drop out is because the patient feels healed or some patients reported feels nauseous, dizzy and feels other uncomfortable effects" -Nurse-

TB patients take anti TB drugs were not according to recommendations from health professional workers as stated:

"The method of taking medication is not according to the recommended three drugs as well as one drink, but they take the drugs one by one up to four times in a day" -Medical doctor-

"Diagnosing, having difficulty removing the sputum even though it has been taught, thus affecting the results of the examination, health workers believe that clinical symptoms indicate $T B$ so that the examination is referred to Thompson's examination with X-rays" whereas the significant result of TB diagnosis was on BTA basis "-analyst-

\section{Barriers from Health Service Facilities Aspects Access to health services}

Public health professional workers stated obstacles related to TB treatment in the form of difficulties in access to health care facilities in the form of distance from public health center that deal with one area farther from the public health center that handles other areas, which are stated as follows:

"Regional issues was a problem that interfere the TB treatment. We (health care professional workers) unable to refuse patients from other regions. The problem is that we can not evaluate patients from other regions in their home, because we have to return the task to the public health center which covered the patients' area, that condition caused the dropout rate is high"-Nurse

"Access to health centers in the same area is further from other health centers, so it is difficult to visit or want to contact" - Nurse-

Distant of public health services from house of TB patients is also an obstacle in handling TB patients:

"Far distant, is the reason from TB patients to drop out" -Nurse-

\section{Lack of Human Resources}

The practice of public health center professional workers to actively find $\mathrm{TB}$ cases is still not implemented:

"Case finding habits to find cases are still not used by health workers, because it is a new program from government and we still not understand how to do it in community" - medical doctor-

The number of public health center professional workers who handle TB is limited with a high workload:

"The number of public health center professional officers is limited" -Nurse-

The burden of work of many public health center professional workers makes the handling of TB in the community less than optimal:

"The task of program holders is so much that it needs to be activated for TB cadres /community health workers in the community" -Nurse-

"Once a year there is counseling but not evenly distributed, counseling per village that is financed" Nurse-

\section{Lack of Cross-sector collaborations}

Public health center professional stated that crosssector collaboration did not work effectively, especially for village administrators as stated:

"The activity of the village administrator is still lacking, when they are invited by the public health center to discuss about health problem they never to never come" -Medical doctor-

"There has been no Drug Treatment Supervisor formation with cadres" -Nurse-

"The Drug Treatment Supervisor must be a close person, the family does not understand, the health worker is far away, the cadre is far away, finally it doesn't work" -Nurse-. 


\section{DISCUSSION}

One of the barriers to the handling of TB disease that comes from TB patients' aspects is the discomfort feeling of anti-TB drugs side effects. Some patients report experiencing the effects of nausea, dizziness, muscle aches which according to them torture themselves and interfere with daily activities so that they decided to stop TB treatment. Previous study stated that the experience of side effects of anti-TB drugs such as joint pain, nausea, dizziness, vomiting (Abbas, 2017) which is uncomfortable for the patients causes the patient to stop treatment (Sang, Obwoge, Kangethe, Ayiro, \& Changeiywo, 2017). Health professional workers need to approach TB patients to provide counseling to increase the motivation of TB patients in completing TB treatment and provide appropriate interventions to reduce discomfort due to the side effects of anti-TB drugs.

Lack of knowledge of the community about TB disease is also a barrier to TB treatment completion. The community considers that a prolonged cough is an ordinary cough symptom and does not need to be examined by a health service. Previous study has suggested that a low level of knowledge regarding TB disease can prolong and delay the time for TB testing (Babatunde, Bismark, Amaechi, Gabriel, \& Olanike, 2015; Getnet, Demissie, Assefa, Mengistie, \& Worku, 2017). Individual behavior associated with the disease will describe the level of individual understanding of the disease(Hassan et al., 2017). Individuals who do not understand about TB disease, including TB symptoms, will assume that TB disease does not need to be addressed as early as possible. The delay in examining TB symptoms will have an impact on the severity of the disease. Health professional workers need to conduct health promotion to the community to improve community knowledge related to TB disease. This is because the TB control and prevention by detecting TB cases in individuals who is at risk of suffering from TB disease will be easier if individuals have good knowledge of TB disease. The government should provide financial assistance for the implementation of TB health promotion, especially in areas with high TB risk and low knowledge of TB, especially in rural areas.

People who suffer from TB also have low selfawareness such as not wanting to come to the public health center to take drugs and evaluate the success of TB treatment. TB patients also still spit carelessly, do not keep the environment clean and do not want to wear a mask to prevent transmission of TB disease even though TB patients know that the disease can be contagious. Prevention of transmission of TB bacteria in TB patients who have infectious status needs to be done especially in the community (World Health Organization, 1999). This is due to sputum management discharges from TB patients who are in an infectious condition a high risk procedure for airborne transmission (Kaul \& Nardell, 2011). The attitude of TB patients to the management of sputum disposal is related to the behavior of sputum discharge (Mei et al., 2012). Patients with TB show a negative attitude towards the management of sputum discharges even though they have been given education by health professional workers. The negative attitude shown by TB patients needs to be reviewed by health workers to determine the right intervention so that TB patients are willing to carry out sputum disposal management in accordance with procedures and safeguarding the environment in order to minimize the risk of transmitting TB bacteria to others.

Non-adherence to treatment is in the form of not taking anti-TB drugs according to the schedule for weeks, feeling bored because they have to take medication every day, and taking medication that is not in accordance with the advice of health workers. The long duration of TB treatment causes physical and emotional exhaustion of TB patients and their families which can have an impact on medication noncompliance (Gebreweld et al., 2018). Health professional workers need to explain the impact that might occur in TB patients if they do not take medication according to the doctor's advice. Health professional workers also need to convey the effect of drug resistance if TB patients do not take medication in accordance with the medical staff's appointments.

Communities in rural areas prefer to seek treatment to alternative, traditional healers rather than to health services related to TB treatment. Previous research also states that almost more than $50 \%$ of $\mathrm{TB}$ patients go to alternatives first to overcome the TB disease (Viney et al., 2014). People have a culture-related belief in their place of residence in the form of taboos to eat certain foods such as protein. People choose to fast and avoid foods that contain high protein when they know that they are diagnosed with TB disease. While other studies have found that there is insufficient high protein food to be consumed by TB patients that causes noncompliance with TB treatment (Mabunda \& Bradley, 2011 ) in the study area found a culture that prohibits the consumption of high protein foods when individual are diagnosed to have TB diseases. Health professional workers need to approach people who influence the tribes in community in the study area to change the community behavior. The government also needs to facilitate by approaching village administrators and people who are considered influential in these tribes to change beliefs regarding protein foods that should not be consumed by sick people including TB patients.

Access to remote health care facilities and the location of public health center that handle one other area is closer than the location of the public health center serving the tribal areas of osing, pandalungan and tengger being one of the obstacles in handling TB disease. In Indonesia there has been a tiered health service where patients must come to a level I health facility that provides basic health services before going to health facilities at level II and III. This means that when TB patients feel sick and need treatment, TB patients cannot go directly to second-level health 
facilities even though the distance from health services is closer than level I health. This of course can be a cause of TB adherence in TB treatment. Previous research has suggested that the distance to a health service place can be a barrier for sufferers to seek treatment at the health care center (Tristiana, Yusuf, Fitryasari, Wahyuni, \& Nihayati, 2018). The government needs to make a breakthrough to overcome the problem of the location of the health service location. In Indonesia, public health centers are still limited to a few places, especially in rural areas. The government can provide TB patients with ease of treatment, for example by providing a mobile TB clinic that can reach all rural areas.

The number of health professional workers handling TB in rural areas is still limited. The limited number of health professional workers is also one of the obstacles. Limitations of TB nurse skills related to intensive case findings (Phetlhu, Bimerew, MarieModeste, Naidoo, \& Igumbor, 2018) also is one of the obstacles in handling TB disease in the community. The limited number of health professional workers and the high workload that must be borne can hinder the effectiveness of TB treatment. The limited number of officers with wide working areas makes TB treatment not optimal. As stated that the lack of funds related to health promotion and the limited number of health workers make extension activities in the community only carried out once a year. This condition is accompanied by a lack of cross-sector cooperation, especially with village officials. The government needs to facilitate so that cooperation can be established, because community empowerment in handling TB disease needs to be done considering the limited number of health workers. The formation of community health cadres, especially in rural areas with sufficient numbers and good skills training, can reduce the number of TB patients in the Tengger, Osing and Pandalungan tribes.

\section{CONCLUSION}

Obstacles related to the handling of TB disease in rural areas in the Tengger, Pandalungan and Osing tribes are obstacles from TB sufferers and also barriers from health facilities. The low level of knowledge and level of public awareness related to TB disease and the persistence of a culture that can inhibit TB handlers need to be addressed. The government in collaboration with health facilities needs to promote health to remote areas in collaboration with people who are considered influential in the area and provide dukun/traditional healer with knowledge of TB in order to accelerate the process of finding TB cases in the community. Problems related to access to health services are also still an issue that often occurs in rural areas. The establishment of mobile TB clinics that can reach all rural areas may be used as an alternative in handling TB in rural areas, especially in Osing, Tengger and Pandalungan.

\section{ACKNOWLEDGE}

The researcher expressed his gratitude to all the study participants who had taken the time to discuss the handling of TB in the rural areas of Osing, Tengger and Pandalungan. The researcher also thanked the University of Jember for giving the opportunity to carry out this research.

\section{REFERENCES}

Abbas, A. (2017). Monitoring Of Side Effects Of AntiTuberculosis Drugs (ATD) On The Intensive Phase Treatment of Pulmonary TB Patients In Makassar. Journal of Agromedicine and Medical Sciences, https://doi.org/https://doi.org/10.19184/ams .v3i1.4093

Ahmed, A., \& Martin, H. (2018). Barriers leading to treatment default among tuberculosis patients in Khartoum State, Sudan: a qualitative study. Open Access Text. https://doi.org/10.15761/CMI.1000152

Babatunde, O. I., Bismark, E. C., Amaechi, E. N., Gabriel, E. I., \& Olanike, A. R. (2015). Determinants of treatment delays among pulmonary tuberculosis patients in Enugu Metropolis, South-East, Nigeria.. 2015;07(11):. doi: Health, $7(11)$, 1506-1516. https://doi.org/10.4236/health.2015.711164.

Gebreweld, F. H., Kifle, M. M., Gebremicheal, F. E., Simel, L. L., Gezae, M. M., Ghebreyesus, S. S., ... Wahd, N. G. (2018). Factors influencing adherence to tuberculosis treatment in Asmara, Eritrea: a qualitative study. J Health Popul Nutr., 37(1). https://doi.org/10.1186/s41043-0170132-y

Getnet, F., Demissie, M., Assefa, N., Mengistie, B., \& Worku, A. (2017). Delay in diagnosis of pulmonary tuberculosis in low-and middleincome settings: systematic review and metaanalysis. BMC Pulm Med., 17. https://doi.org/[10.1186/s12890-017-0551-y]

Hassan, A. O., Olukolade, R., Ogbuji, Q. C., Afolabi, S., Okwuonye, L. C., Kusimo, O. C., ... Ladipo, O. A. (2017). Knowledge about Tuberculosis: A Precursor to Effective TB Control-Findings from a Follow-Up National KAP Study on Tuberculosis among Nigerians. Tuberc Res Treat. https://doi.org/10.1155/2017/6309092

Hutama, H. I., Riyanti, E., \& Kusumawati, A. (2019). Gambaran Perilaku Penderita TB Paru Dalam Pencegahan Penularan TB Paru di Kabupaten Klaten. Jurnal Kesehatan Masyarakat, 7(1).

Kaul, S., \& Nardell, E. (2011). Disposal of Sputum in Home Settings. 


\section{R. E. SULISTYONO ET AL.}

Mabunda, J., \& Bradley, H. (2011). Factors contributing to poor performance of directly observed treatment short-course (DOTS). Mopani District, Limpopo Province and South Africa. Afr J Phys Health Educ Recreation Dance Suppl., 2(1), 93-107.

Mei, L., Tobe, R., Geng, H., Ma, Y., Li, R., Wang, W., ... Xu, L. (2012). A cross-sectional study of sputum handling by and supervision of patients with pulmonary tuberculosis treated at home in China. Biosci Trends., 6(6), 296-302. DOI: $10.5582 /$ bst.2012.v6.6.296

Phetlhu, D. R., Bimerew, M., Marie-Modeste, R. R., Naidoo, M., \& Igumbor, J. (2018). Nurses' Knowledge of Tuberculosis, HIV, and Integrated HIV/TB Care Policies in Rural Western Cape, South Africa. Journal of the Association of Nurses in AIDS Care, 29(6). https://doi.org/https://doi.org/10.1016/j.jana .2018.05.008

Pratiwi, N. L., Betty, R., Hargono, R., \& Widya, N. E. (2012). Kemandirian Masyarakat dalam Perilaku Pencegahan Penularan TB Paru. Buletin Penelitian Sistem Kesehatan, 15(2).

Sagbakken, M., Frich, J. C., \& Bjune, G. (2008). Barriers and enablers in the management of tuberculosis treatment in Addis Ababa, Ethiopia: a qualitative study. BMC Public Health, 8(11). https://doi.org/10.1186/1471-2458-8-11

Sang, R. K. A., Obwoge, R. O., Kangethe, S., Ayiro, L. P., \& Changeiywo, J. M. (2017). Patient Factors Which Contribute to Non-adherence to TB Treatment in Kericho and Nakuru Counties of Kenya. Science Journal of Public Health, 5(4), 329-334.

https://doi.org/10.11648/j.sjph.20170504.18

Streubert, H., \& Carpenter, D. (2003). Qualitative research in nursing: advancing the humanistic imperative. Philadelphia: Lippincott Williams \&
Wilkins.

Sullivan, B. J., Esmaili, B. E., \& Cunningham, C. K. (2017). Barriers to initiating tuberculosis treatment in sub-Saharan Africa: a systematic review focused on children and youth. Glob Health Action., 10(1). https://doi.org/10.1080/16549716.2017.1290 317

Tristiana, R. D., Yusuf, A., Fitryasari, R., Wahyuni, S. D., \& Nihayati, H. E. (2018). Perceived barriers on mental health services by the family of patients with mental illness. International Journal of Nursing Sciences, 5(1), 63-67. https://doi.org/https://doi.org/10.1016/j.ijns s.2017.12.003

Tuharea, R., Suparwati, A., \& Sriatmi, A. (2014). Analisis Faktor-Faktor yang Berhubungan dengan Implementasi Penemuan Pasien TB Paru dalam Program Penanggulangan $\mathrm{Tb}$ di Puskesmas Kota Semarang. Jurnal Manajemen Kesehatan Indonesia, 2, 168-178.

Usaid. (2017, June). Pengendalian Tuberkulosis di Indonesia: Tantangan. News and Information.

Viney, K. A., Johnson, P., Tagaro, M., Fanai, S., Linh, N. N., Kelly, P., ... Sleigh, A. (2014). Tuberculosis patients' knowledge and beliefs about tuberculosis: a mixed methods study from the Pacific Island nation of Vanuatu. BMC Public Health., 14. https://doi.org/10.1186/14712458-14-467

WHO. (2013). Systematic screening for active tuberculosis: principles and recommendations. Genewa: World Health Organization.

WHO. (2017). Global Tuberculosis Report 2017. Who. https://doi.org/WHO/HTM/TB/2017.23

World Health Organization. (1999). Tuberculosis Infection Control in The Era of Expanding HIV Care and Treatment. 